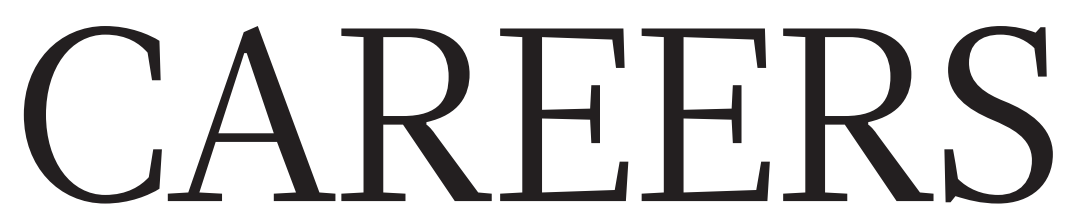

TAKE THE LEAP Collaborations lead to Pfizer post for long-time NIH researcher $\mathbf{p . 1 3 1}$
BLOG Personal stories and careers counsel http://blogs.nature.com/naturejobs
NATUREJOBS For the latest career

listings and advice www.naturejobs.com

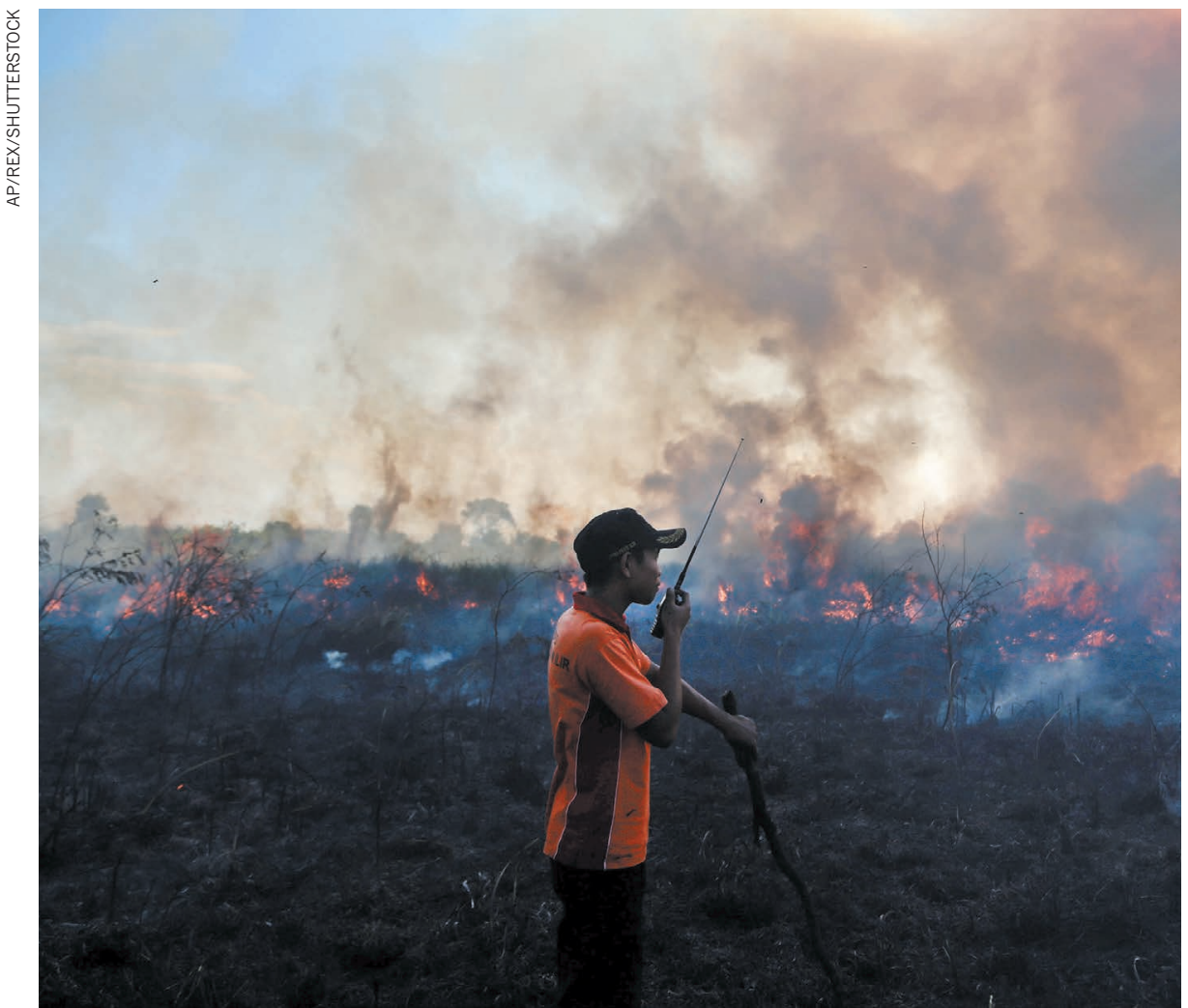

A prize for mapping Indonesia's peatlands could help to stop illegal clearances, which are a fire risk.

\title{
COMPETITIONS
}

\section{Grand challenges}

\section{Scientists lured by big-prize competitions should weigh contests' aims and non-monetary benefits before entering.}

\section{BY VIRGINIA GEWIN}

S onia Silvestri was trained to use satellite imagery to map coastal vegetation and salt marshes. But when a colleague e-mailed her last year about the Indonesian Peat Prize - a competition to determine how best to map the extent and depth of peatlands in Indonesia - it sparked her interest.

Peatlands result from the accumulation of dead plants on wetlands to form thick, carbon-rich layers. In Indonesia, where peatlands are drained and cleared for oil-palm plantations, resulting fires often send thick smoke throughout the region and release vast amounts of greenhouse gases into the atmosphere: in 2015, fires in the region emitted hundreds of millions of tonnes of carbon dioxide. To boost the enforcement of a nationwide moratorium on peatland development, the Indonesian government worked with the David and Lucile Packard Foundation in the United States to create the prize, which carries a US $\$ 1$-million purse.

Silvestri, then a remote-sensing researcher at Duke University in Durham, North Carolina (where she maintains a courtesy appointment), theorized that scientists could map peat by combining satellite images with airborne electromagnetic data, which are often used to find layers of coal or minerals below ground. She and a wetland ecologist from Duke put together an international team that includes geophysicists, foresters and environmental consultants. The team is now one of five finalists for the prize, whose winner will be announced in February 2018.

"It's been an exciting adventure," says Silvestri, who leads the DAG4Peat team. "This prize gave me the opportunity to follow a new direction in my career, but it was also risky, something that would have been difficult to get funded via traditional grants."

The use of goal-driven prizes to spur innovation has increased since the success of the Ansari X Prize in 1996, which aimed to accelerate the development of low-cost space flight (see 'Glittering prizes'). The X Prize Foundation in Culver City, California, offered a \$10-million prize for the first non-governmental organization to launch a reusable crewed craft into space. By the time the prize was awarded, in 2004, some 26 teams had signed on.

Innovation prizes offer cash incentives to solve vexing problems. They are now a staple throughout US federal agencies, including NASA and the Defense Advanced Research Projects Agency, as well as in philanthropic organizations such as the Roddenberry Foundation in Encino, California. These one-off contests pit teams of scientists - from companies, consulting agencies and academia - against each other.

Prize competitions typically offer a substantial purse to the first team to achieve a specific goal. Some competitions offer milestone cash awards to help teams continue to develop their idea. 'Challenges' - for example, those offered by the US Agency for International Development (USAID) or by Cancer Research UK - often aim to spark innovation in a research area, and typically reward a set of selected teams with seed funding to develop their ideas and to compete for more funds to conduct research or commercialize the project.

Unlike conventional federal investment in research and development - roughly $\$ 113$ billion in 2016 in the United States alone - or awards such as the Nobel prizes, which honour scientists' past work, these prizes and challenges typically aim to translate science into tangible solutions, such as new devices or research capabilities, that will further the awarding organization's aims. The competitions typically take at least one year, if not several, and often require 
competitors to reach project milestones.

Europe took longer than the United States to warm to the trend, says Olivier Usher, research manager at the Challenge Prize Centre at Nesta, an innovation foundation based in London. However, the European Commission (EC) is inviting submissions for nine Horizon Prizes up to 2019, including a $€ 1.5$-million (US\$1.8-million) prize to find ways to help cut atmospheric $\mathrm{CO}_{2}$ emissions.

Yet competing for prize or challenge funding can be tricky for academic researchers, particularly those in the early stages of their careers. Unlike grants, prizes pay off in prestige, expanded networks and media attention for the finalists, but typically only one winner gets the purse (although some competitions, such as the Google Lunar X Prize or the Roddenberry Prize, reward finalists with smaller sums).

Aspiring prizewinners will need to secure funding to compete. They should seek competitions whose goals and winning criteria are clearly articulated, and will need to discern whether entering the competition will significantly improve their science.

\section{SUCCESS STORIES}

Silvestri, now based at the University of Padua in Italy, admits that her gamble paid off. Earlier this year, she won a Marie Curie Fellowship, funded by the EC, to expand on how the techniques that her team is exploring could be used to map peatlands on a global scale. Entering the prize competition allowed her to develop new capabilities that could prove useful to any country with peatlands.

$\mathrm{Hao} \mathrm{Hu}$, a photonics scientist at the Technical University of Denmark in Lyngby, and his team were already working on an international project, funded by a €9-million Danish Research Council grant and an EC-Japan grant, when they won the $€ 500,000$ Horizon Prize in 2016 for breaking optical-data transmission barriers in telecommunications. "The prize opened new doors for me," says Hu. "It's the start of brandnew research."

Although only the winner or winners get financial benefits, the organizations that run prize competitions argue that all entrants stand to gain recognition. "While the competition winner reaps the most benefits, other entrants also get increased visibility," says Walt Reid, who directs the Packard Foundation's conservation and science programme and came up with the idea of the Indonesian Peat Prize.

Competing also expands entrants' reputation and experience, adds Robert Benedict, a cofounder of Context Partners in Portland, Oregon, which designed the Peat Prize. He urges scientists to consider the perks of competing, such as enhancing their $\mathrm{CV}$, expanding their network or gaining access to a particular field site to test an experiment. Charlie Brown, co-founder of Context Partners, advises would-be participants to look for clear

\begin{tabular}{|c|c|c|c|}
\hline \multicolumn{4}{|c|}{$\begin{array}{l}\text { GLITTERING PRIZES } \\
\text { Some high-profile competitions launched in the past decade. }\end{array}$} \\
\hline Prize competition & Duration & Stated goals & Prize money \\
\hline $\begin{array}{l}\text { Wendy Schmidt Ocean } \\
\text { Health X Prize }\end{array}$ & 2013-15 & $\begin{array}{l}\text { Low-cost, durable pH } \\
\text { sensor to monitor ocean } \\
\text { chemistry }\end{array}$ & US $\$ 2$ million; awarded 2015 \\
\hline Roddenberry Prize & 2016 & $\begin{array}{l}\text { Innovations for the } \\
\text { future }\end{array}$ & $\begin{array}{l}\text { Winner }(\$ 400,000) \text { and four } \\
\text { runners-up }(\$ 150,000 \text { each }) \text {; } \\
\text { awarded } 2016\end{array}$ \\
\hline Longitude Prize & 2014-19 & $\begin{array}{l}\text { Reduce the use of } \\
\text { antibiotics }\end{array}$ & $£ 10$ million ( $\$ 13.16$ million) \\
\hline $\begin{array}{l}\text { Shell Ocean Discovery } \\
\text { X Prize }\end{array}$ & $2015-18$ & $\begin{array}{l}\text { Advance ocean } \\
\text { exploration }\end{array}$ & $\$ 7$ million \\
\hline Horizon Challenges & $2013-20$ & $\begin{array}{l}\text { Solutions to social } \\
\text { issues in the European } \\
\text { Union }\end{array}$ & $\begin{array}{l}€ 1 \text { million to } € 2 \text { million } \\
\text { ( } \$ 1.18 \text { million to } \\
\$ 2.24 \text { million) }\end{array}$ \\
\hline
\end{tabular}

articulation of the problem statement, the competition's eligibility requirements and criteria for winning. Aspirants should also make sure that the research will help them to reach their career goals whether they win or not.

Muhammad Zaman, a biomedical engineer at Boston University in Massachusetts, won a \$2-million award in 2014 to scale up PharmaChk, his fast, portable device to screen for counterfeit or substandard medicines. The Saving Lives at Birth challenge winner was funded by USAID, the Gates Foundation, Grand Challenges Canada and others, and built on an earlier $\$ 250,000$ seed grant from the programme. Before this, most of Zaman's funding had come from the US National Institutes of Health or the US National Science Foundation. "Through competing, we forged new collaborations with people in East Asia and West Africa that wouldn't otherwise have happened at all," he says.

Zaman marvels that his work will now have an impact beyond what he could have

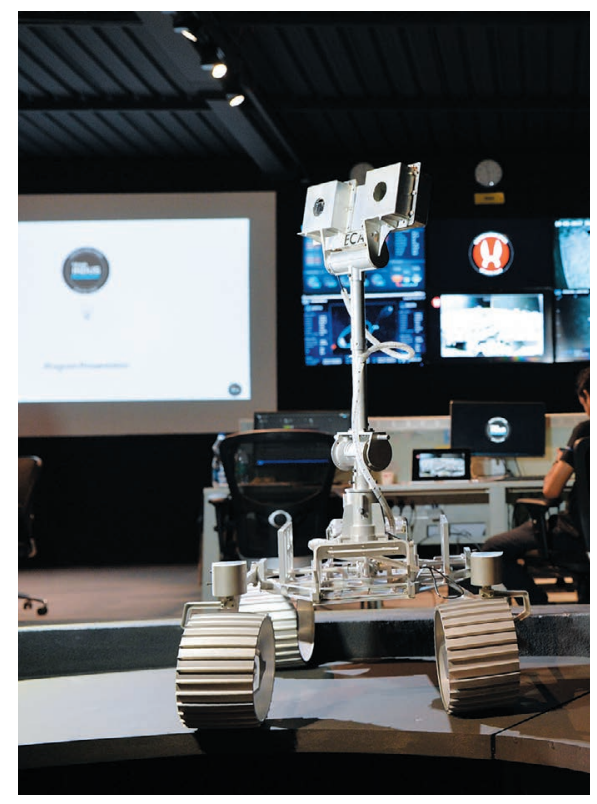

Model of an unmanned lunar rover developed by Team India for the Google Lunar X Prize. accomplished through his academic research alone. "It's phenomenal that the prize money has helped a small research group like ours to affect millions of people," he says.

\section{WILL IT BE WORTH IT?}

Prizes create the infrastructure and competition necessary to launch new branches of scientific exploration, but competition rules may shift or be unforgiving, which can disrupt the playing field. And the final purse may not be what the prize organization had originally advertised. Anil Vaidya, a London-based medical engineer and industry consultant, assembled a team to compete in the \$10-million Qualcomm Tricorder X Prize, launched in 2012, to develop SCANurse, a precision-diagnostics device. He was happy to take the risk to develop and promote the team's device, but doubts that he'd want to invest as much (his team spent at least $\$ 100,000$ ) to compete again. As it was, his team had to drop out of the competition because of a US Customs and Border Protection glitch.

John Thornton, chief executive of Astrobotic, a space-robotics company based in Pittsburgh, Pennsylvania, entered his company into the Lunar X Prize competition to be the first private firm to land on the Moon; the competition initially promised $\$ 20$ million to the winner. His team alone met the three milestones, netting $\$ 1.7$ million in prize money, but Thornton says that the team spent far more than that throughout the competition. Astrobotic dropped out of the competition late last year, saying that it could not accelerate its research and development to meet the launch deadline.

The paperwork required to enter a prize competition is minimal compared with that for most grants, but entrants need immediately to grab the interest of reviewers who are unlikely to specialize in their research area. "You have to explain how you are going to change the world to a panel that is not in your scientific domain," says Trey Ideker, a systems biologist at the University of California, San Diego. As a runner-up in the inaugural Roddenberry Prize 
competition in 2016 - which sought ways to address social issues such as education or poverty - his team received $\$ 150,000$ to create cancer-cell maps.

Competitions often draw a huge number of entrants, lowering the likelihood of winning and making it difficult to capitalize on the marketing value of the prize or to raise interim funds, says Thornton. A \$30-million USAID competition in 2016 to combat the Zika virus received more than 900 applications in just 9 weeks, but only 21 applicants received funding for further development. More than 600 groups submitted proposals to the Roddenberry Prize, which awarded a cash prize to one winner and four runners-up.

The financial cost of entering a contest can deter aspirants who cannot devote time and resources to a project when they are not getting paid up front. Zaman, who has participated in several competitions, has received discretionary funds from his department and the university in the early stages of prize-project development. "If I didn't have those, it would be a challenging situation," he acknowledges. He says that the university provided him with a line of credit for institutional funds, which allowed him to meet initial competition milestones.

But universities' familiarity with prizes and their potential benefits varies, as does their support. Silvestri struggled to secure interim funding to compete in the peat prize. She couldn't get university funds to cover her fieldwork; administrators cited concerns about whether the university could recover the expenses even if she won, because prize funders often do not allow the purse to be used for recompensing institutions' indirect costs. Eventually, Silvestri got funding from Stanford University in California and the Duke University Wetland Center for her fieldwork outside Indonesia.

Prize administrators encourage entrants to explore a range of funding options. Paul Bunje, a senior scientist for energy and environment at the X Prize Foundation, advises contacting networks of alumni, who are often eager to see their alma mater in high-profile competitions.

Collaborative networks may also be able to help. Many competitions require interdisciplinary efforts, which can diffuse the financial load, says Reid. "Having team members at a variety of institutions can help raise initial funding," he says.

Despite the large purses that many prizes carry, Bunje says that his organization never hears competitors report that they entered the challenge for the money alone. "These are driven, caring people," he says, "who want to do something big and exciting."

Virginia Gewin is a freelance writer in Portland, Oregon.

\section{TURNING POINT}

Industry immigrant

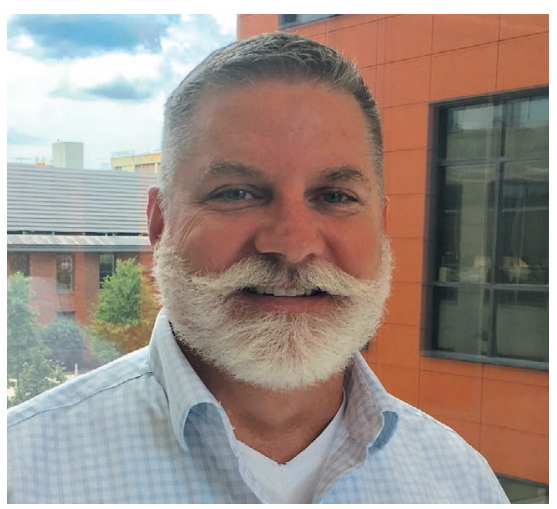

Immunologist Thomas Wynn left a 20-year career at the US National Institutes of Health (NIH) in Bethesda, Maryland, earlier this year to lead research on inflammation at Pfizer in Cambridge, Massachusetts.

\section{Why did you leave the NIH for industry?}

I've collaborated with big pharmaceutical and biotechnology companies since the mid1990s. I worked with Amgen to investigate the therapeutic potential of different antibodies in models of inflammation and fibrosis, and with Genentech we examined inflammatory pathways in asthma. I've negotiated agreements with Pfizer and other pharmaceutical companies to move basic science on fibrosis into preclinical trials conducted collaboratively with the NIH. I was doing so much with industry that I decided to explore what it would be like to do this work full-time.

Did the current US administration affect your decision?

It's not a major reason for my move at all. It's unfortunate that the administration is not, at least outwardly, as supportive of science as previous administrations were. But I put my faith in Congress and the US Senate, which have always shown support for science and for the NIH.

\section{How would you describe morale at the NIH?} Surprisingly upbeat despite what's going on in the news and the threat of NIH budget cuts. The fact that NIH director Francis Collins is still at the top has helped.

How did your colleagues react to your move? A lot of people were shocked.

What will be your biggest challenge as you move into industry?

At the NIH, labs are a one-person show.
People develop collaborations, but they are fragmented. At Pfizer, groups interact seamlessly. I get to work with geneticists, chemists, molecular biologists and bioengineers. The culture is different here - it is focused on translating the best ideas into new medicines.

\section{How did the move affect your NIH research group?}

It was a slow process accepting the job here because of worrying about my research family at the NIH. Nothing stopped immediately. Most of my lab is still there. Three members have accepted positions at Pfizer. Everybody has until 2018 to finish up projects, publish and make their own career moves.

\section{How did you come to work at the NIH?}

After getting my $\mathrm{PhD}$ at the University of Wisconsin-Madison, researching how macrophages kill tumour cells, I wanted to work more on disease pathogenesis. My $\mathrm{PhD}$ mentor was married to a parasitologist. They suggested I merge my interests in molecular immunology and parasitology. I wrote to several people doing parasite immunology at the $\mathrm{NIH}$ and was invited to work as a postdoc in the laboratory of parasitic diseases at the National Institute of Allergy and Infectious Diseases in Bethesda.

\section{Describe your NIH career.}

I was a postdoc at the NIH from 1991 to 1995 , and then a staff researcher until 1997. Opportunities for full-time employment at the NIH were few and far between, so I began interviewing for jobs outside. But a retirement opened up a slot for a tenure-track investigator. I had other offers on the table when the NIH began recruiting, but I ended up with the position in 1997.

\section{Do you think you'll get more accomplished in industry?}

That hits the nail on the head - it's what I find most exciting.

\section{You did a lot of mentoring at NIH. What made} for successful mentees?

I mentored more than 20 postdocs, as well as graduates and undergraduates, during my time at NIH, where I was also scientific director of an NIH-Oxford-Cambridge Scholars programme. The junior scientists who tend to stumble are the ones who don't reach out for help or forge collaborations with people. It's important to take advantage of expertise.

INTERVIEW BY VIRGINIA GEWIN

This interview was edited for clarity and length. 